\title{
3.1. Różnorodność i inkluzja w edukacji - wybrane aspekty wspierania uczniów z doświadczeniem migracji
}

DOI: $10.47050 / 65591838.278-287$

Anna Młynarczuk-Sokołowska, Katarzyna Szostak-Król

Celem rozdziału jest ukazanie podstawowych zagadnień dotyczących wspierania procesów inkluzji oraz edukacji dzieci z doświadczeniem migracji w ramach edukacji formalnej. Artykuł składa się z dwóch głównych części. Pierwsza poświęcona jest analizie sytuacji dzieci z doświadczeniem migracji, z uwzględnieniem ich szkolnego funkcjonowania. W drugiej zostały zaprezentowane prawne możliwości wspierania imigrantów, uchodźców oraz reemigrantów oraz przykłady dobrych praktyk edukacyjnych w tym zakresie (organizacja oddziałów przygotowawczych, nauczanie języka polskiego jako obcego, realizacja zajęć wyrównawczych itd.).

\section{Słowa kluczowe:}

\section{uczniowie z doświadczeniem migracji \\ inkluzja}




\subsection{Diversity and inclusion in education - selected aspects of supporting students with migration experience}

DOI: $10.47050 / 65591838.278-287$

Anna Młynarczuk-Sokołowska, Katarzyna Szostak-Król

The aim of the chapter is to present vital issues related to supporting inclusion and education processes of children with migrant background in the field of formal education. The article consists of two main parts. The first one is devoted to the analysis of student with migrant experience situation including their school functioning. The second one presents legal and methodical possibilities of supporting immigrants, refugees and re-emigrants and examples of good educational practices in this field (welcome classes, teaching Polish as a foreign language, implementation of remedial classes, etc.).

\section{Keywords:}

\section{students with a migrant background \\ inclusion}


W globalizującym się świecie migrant nie jest już niespotykanym zjawiskiem społeczno-kulturowym, anomalią czy jednostką "egzotyczną" ze względu na kolor skóry, język, którym się posługuje, czy odmienną kulturę. Jego obecność w przestrzeni publicznej zaczyna być (a w wielu środowiskach już jest) czymś naturalnym. Obecnie coraz więcej ludzi, motywowanych różnymi czynnikami, decyduje się na zmianę miejsca zamieszkania. Grupę migrantów tworzą osoby dobrowolnie opuszczające swoje państwo, dla których priorytetem jest poprawa własnej sytuacji ekonomicznej lub osiągnięcie awansu zawodowego w nowym miejscu, a także jednostki wyjeżdzające w obawie o utratę zdrowia lub życia w związku z sytuacją w kraju pochodzenia (problem uchodźstwa). Cechą znamienną dzisiejszych czasów są również reemigracje, wynikające z potrzeby powrotu do domu, porażki migracyjnej czy chęci spędzenia okresu emerytalnego w rodzinnych stronach. W związku z intensyfikacją tych zjawisk migrantami coraz częściej są dzieci.

Zróżnicowanie kulturowe każdego społeczeństwa naturalnie znajduje swoje odzwierciedlenie w placówkach edukacyjnych. Obecnie odbiorcami działań oświatowych są nie tylko członkowie grupy większościowej oraz mniejszości autochtonicznych, ale także nowe kręgi uczniów z doświadczeniem migracji, którzy mają nieraz diametralnie odmienne od większości "kulturowe oprogramowanie" (Hofstede 2010).

\section{Zarys sytuacji dzieci z doświadczeniem migracji}

Grupę uczniów z doświadczeniem migracji w polskim systemie oświaty tworzą najczęściej dzieci imigrantów ekonomicznych, osób, które uzyskały w Polsce status uchodźcy bądź inną formę ochrony prawnej lub ubiegają się o nią, a także reemigrantów. W wielu wypadkach migracje niosą ze sobą duży potencjał edukacyjny, w innych wiążą się z kompletowaniem bagażu trudnych doświadczeń autobiograficznych (Kożyczkowska, Młynarczuk-Sokołowska 2018). Sytuacja uczniów z doświadczeniem migracji jest zróżnicowana i determinowana wieloma czynnikami: specyfiką doświadczeń życiowych, przynależnością kulturową, religijną, statusem społecznym i ekonomicznym, poziomem znajomości języka i kultury polskiej itd. Analiza treści literatury

1 Definicja uchodźcy - zob. Konwencja dotycząca statusu uchodźców, sporządzona w Genewie dnia 28 lipca 1951 r. art. 1 (Dz.U. z 1991 r. nr 119 poz. 515). 
przedmiotu oraz nasze doświadczenia wynikające $z$ wieloletniej pracy w środowisku zróżnicowanym kulturowo pokazują, że często inaczej przebiegają procesy inkluzji i edukacji dzieci imigrantów zarobkowych (np. ukraińskich) i reemigrantów niż dzieci uchodźców (np. z Czeczenii), którzy wraz z rodzicami opuścili swoją ojczyznę w obawie o utratę życia, zdrowia lub bezpieczeństwa. Dzieje się tak zwłaszcza wtedy, gdy mają oni trudne doświadczenia i różnią się znacznie od członków społeczeństwa przyjmującego w zakresie kulturowym i religijnym, posługiwania się językiem polskim oraz znajomością polskiej kultury (Młynarczyk-Sokołowska, Szostak-Król 2016). Niejednokrotnie efektywność pracy z osobami z doświadczeniem migracji oraz heterogenicznym zespołem zależy od dodatkowego wsparcia udzielonego poszczególnym uczniom w formie np. pomocy psychologicznej, nadprogramowej nauki języka polskiego jako obcego, zajęć wyrównawczych.

Realizacja modelu edukacji inkluzyjnej, umożliwiającej efektywną pracę z dziećmi z doświadczeniem migracji oraz grupą zróżnicowaną kulturowo, jest wielkim wyzwaniem stojącym przed edukacją w Polsce i w innych krajach europejskich. Temat ten był niejednokrotnie szeroko dyskutowany na szczeblu międzynarodowym. Zgodnie z treścią konkluzji Rady Europy w sprawie kształcenia dzieci ze środowisk migracyjnych, edukacja ma się istotnie przyczyniać do ich udanej integracji w społeczeństwach europejskich. Wobec tego państwa członkowskie zobowiązane są do zastosowania odpowiednich środków (na szczeblu lokalnym, regionalnym lub krajowym) w celu zapewnienia wszystkim dzieciom równych szans oraz wsparcia niezbędnego do pełnego rozwoju ich potencjałów, niezależnie od tego, z jakich środowisk pochodzą (Council Conclusions of 26 November 2009).

Mimo wielu modelowych działań podejmowanych w polskich placówkach edukacyjnych efektywna praca z imigrantami, uchodźcami i reemigrantami oraz z grupą zróżnicowaną kulturowo wymaga projektowania przemyślanych rozwiązań systemowych (i doskonalenia już istniejących), a także międzykulturowej metodyki, uwzględniającej ustawiczne diagnozowanie potrzeb wszystkich uczestników procesu uczenia się, bez względu na przynależność narodową, wyznawaną religię czy sytuację życiową. Osoby z doświadczeniem migracji to często 
uczniowie ze specjalnymi potrzebami edukacyjnymi2, dla których niezbędna jest m.in. indywidualizacja procesu kształcenia.

Polskie prawo umożliwia dostęp do powszechnego systemu oświaty każdemu dziecku przebywającemu na terenie kraju - bez względu na jego status prawny. Gwarancję uczestnictwa w edukacji dzieci migrantów stanowi art. 70 Konstytucji Rzeczypospolitej Polskiej. Podstawy nieodpłatnego kształcenia cudzoziemców oraz podejmowania działań służących inkluzji w procesie edukacji regulują zapisy ustawy Prawo oświatowe z dnia 16 grudnia 2016 r. i Rozporządzenia Ministra Edukacji Narodowej z dnia 23 sierpnia 2017 r. w sprawie kształcenia osób niebędących obywatelami polskimi oraz osób będących obywatelami polskimi, które pobierały naukę w szkołach funkcjonujących w systemach oświaty innych państw.

Rozpoczęcie edukacji w nowym kraju zamieszkania lub powrót do systemu edukacyjnego państwa pochodzenia (reemigracje) wymaga od dzieci zaadaptowania się do nowych realiów, z którymi wiążą się inne niż dotychczas oczekiwania. Uczniowie z doświadczeniem migracji, szczególnie uchodźstwa, mogą borykać się z wieloma problemami utrudniającymi proces adaptacji w systemie edukacyjnym. Pierwszą barierą, z którą się stykają się osoby pochodzące z innych krajów, a także często reemigranci, jest nieznajomość lub słaba znajomość urzędowego języka komunikacji. Rozwijanie kompetencji komunikacyjnych w zakresie porozumiewania się w języku polskim jest pierwszoplanowym czynnikiem aktywnej partycypacji w edukacji szkolnej. Bariera językowa powoduje nie tylko utrudnienia w codziennym porozumiewaniu się, ale także kłopoty ze zrozumieniem tekstów pisanych i poleceń w języku polskim (Młynarczuk-Sokołowska, Szostak-Król 2016).

Zdarza się, że migranci w początkowym okresie pobytu w Polsce przeżywają szok kulturowy (Boski 1998) bądź powrotny szok kulturowy (reemigranci) ${ }^{3}$ (Grzymała-Moszczyńska 2015). Ten pierwszy jest tym bardziej odczuwalny, im większe są różnice między kulturą oraz językiem macierzystego kraju a nowego, do którego trafiają cudzoziemcy. Powrotny szok kulturowy wiąże się z kolei ze zmianami zachodzącymi organizacji i udzielania pomocy psychologiczno-pedagogicznej w publicznych przedszkolach, szkołach i placówkach (Dz.U. z 2017 r. poz. 1591), par. 2, pkt 1-3. 
w przestrzeni społeczno-kulturowej państwa pochodzenia w okresie nieobecności migranta, a także tymi w jego tożsamości (Barzykowski, Grzymała-Moszczyńska i in. 2013).

Proces wchodzenia w krąg odmiennej rzeczywistości społeczno-kulturowej (akulturacja) dotyczy również dzieci (Borkowska 2016). Jest długotrwały i wiąże się z ustawicznym gromadzeniem nowych, nieraz bardzo trudnych doświadczeń, na wszystkich płaszczyznach aktywności ludzkiej. Dzieciom uchodźców proces akulturacji utrudniają traumatyczne przeżycia z kraju pochodzenia. Mogą być one przyczyną zarówno wycofania, apatii, zamknięcia się w sobie, jak i nadpobudliwości oraz zachowań agresywnych. Akulturacja może przybierać wiele form i przynieść różne skutki. Wiąże się ze zmianami w systemie wartości, zachowaniach oraz w tożsamości. Omawiany proces może kończyć się integracją, asymilacją, separacją bądź marginalizacją. Optymalną strategią akulturacji jest integracja, będąca wynikiem spotkania i dialogu między kulturą kraju przybyszów i kraju przyjmującego (Berry 1998).

Sprzeczności wynikające z wyznawanych wartości, przyjętych norm kulturowych oraz złożona tożsamość kulturowa sprawiają, że dzieciom z doświadczeniem migracji nie jest łatwo wejść w nową rzeczywistość szkolną. Zdarza się, że odmienność kulturowa i nakładające się na nią niskie kompetencje (bądź ich brak) w zakresie porozumienia się w języku polskim powodują, że są one izolowane od grup rówieśniczych. By zaaklimatyzować się w nowej szkole, potrzebują życzliwości ze strony rówieśników oraz kadry pedagogicznej, a także wsparcia dopasowanego do ich indywidualnych, zdiagnozowanych potrzeb.

\section{Ku inkluzji dzieci z doświadczeniem}

\section{migracji - aspekty prawne i metodyczne}

Inkluzja i postępy edukacyjne uczniów z doświadczeniem migracji są w dużej mierze warunkowane możliwościami, które stwarza im szkoła. Dlatego kadra pedagogiczna powinna dysponować kompetencjami niezbędnymi do pracy w środowisku zróżnicowanym kulturowo oraz znać prawne możliwości wspierania uczniów tego typu w trakcie edukacji szkolnej.

Praca w warunkach zróżnicowania kulturowego jest nieprzewidywalna oraz stwarza wiele wyzwań. Wymaga od nauczycieli otwartych postaw, rozległej wiedzy oraz wielu umiejętności. Nie istnieje uniwersalny model programowy i metodyczny, który umożliwiłby radzenie sobie we 
wszystkich sytuacjach pojawiających się na stykach kultur. W dynamicznie zmieniającej się rzeczywistości społeczno-kulturowej trudno uzyskać wykształcenie, które można uznać za wystarczające. Kompetencje osób zaangażowanych w praktykę edukacyjną (w tym międzykulturową) powinny być ustawicznie rozwijane - zarówno w ramach procesu uczenia się przez całe życie, samokształcenia, w dialogowej relacji nabywania wiedzy teoretycznej, jak i przez praktyczne doświadczenia. Niezwykle ważna jest w tej sytuacji gotowość do realizacji edukacji w środowisku międzykulturowym (Lewowicki 2008) i tym samym korzystania z potencjału istniejącego w grupach zróżnicowanych, z którymi pracują pedagodzy i nauczyciele, oraz poszukiwania własnych, wrażliwych kulturowo, rozwiązań metodycznych. Trzeba pamiętać, że to nauczyciele i edukatorzy najczęściej wprowadzają uczniów w polskie realia i dziedzictwo, a także w skomplikowane zagadnienia międzykulturowe (różnice, komunikacja itp.). Rozpoczęcie pracy ze środowiskami migracyjnymi i z grupą zróżnicowaną kulturowo daje możliwość wyjścia poza rodzimą perspektywę postrzegania świata oraz monokulturową metodykę działania.

Efektywna praca z uczniami z doświadczeniem migracji w grupie zróżnicowanej kulturowo wymaga projektowania procesu edukacyjnego na podstawie rozpoznania wymagań poszczególnych uczniów. Uwzględnianie specjalnych potrzeb edukacyjnych imigrantów, uchodźców i reemigrantów (a także innych grup uczniów) wiąże się z koniecznością indywidualizowania treści kształcenia, wymogów szkolnych oraz procesu oceniania cząstkowego i końcowego. Powstaje zatem pytanie: jak efektywnie realizować zajęcia przedmiotowe w grupie o zróżnicowanych potrzebach edukacyjnych?

Jedną ze sprawdzonych metod w tym zakresie jest preparowanie tekstów, które polega na leksykalnym i gramatycznym upraszczaniu treści przewidzianych w programach kształcenia i projektowaniu zadań dydaktycznych nawiązujących bezpośrednio do zmodyfikowanych materiałów (Bernacka-Langier, Janik-Płocińska i in. 2010). Dzięki zastosowaniu tej metody wszyscy uczniowie równolegle mogą realizować treści kształcenia zgodnie ze swoimi możliwościami. W tym wypadku, w celu zachowania zadowalającej dynamiki pracy, niezbędne jest również wsparcie nauczyciela oraz uczniów przez innego pedagoga lub asystenta międzykulturowego.

Zgodnie z obowiązującym w Polsce prawem uczniowie z doświadczaniem migracji mają możliwość nauki w tzw. oddziałach przygo- 
towawczych (welcome class) ${ }^{4}$, co umożliwia realizację programów kształcenia przez jeden rok szkolny (bądź okres krótszy lub dłuższy, w zależności od potrzeb) w małej grupie, liczącej maksymalnie 15 osób, zgodnie z ich indywidualnymi wymaganiami rozwojowymi i edukacyjnymi. Mogą także skorzystać z dodatkowych lekcji języka polskiego jako obcego. Podstawą procesu edukacji w oddziałach przygotowawczych powinna więc być indywidualizacja treści kształcenia, wymagań szkolnych oraz sposobu oceniania cząstkowego i końcowego, dostosowana do kompetencji (także językowych) ucznia.

W Szkole Podstawowej nr 221 w Warszawie funkcjonuje aż pięć oddziałów przygotowawczych, w których uczą się dzieci począwszy od wieku wczesnoszkolnego, na gimnazjum kończąc. W klasach tych znajdują się uczniowie z doświadczeniem migracji z różnych zakątków świata (Ukraina, Indie, Wietnam, Tadżykistan, Irak i Azerbejdżan).

Niezależnie od tego, czy w szkole zostanie utworzony taki oddział czy nie, uczniowie z doświadczeniem migracji mają prawo do dodatkowej nauki języka polskiego ${ }^{5}$ (w wymiarze nie niższym niż dwie godziny lekcyjne tygodniowo), którą organizuje organ prowadzący placówkę (na wniosek dyrektora). Zajęcia prowadzone są w formie lektoratu z języka polskiego jako obcego, a ich zadaniem jest intensywne rozwijanie kompetencji lingwistycznych słuchaczy. Skuteczność tych lekcji zależy od regularnego udziału dzieci. Z naszych doświadczeń wynika, że motywację i frekwencję $w$ dużej mierze warunkują metody i formy pracy stosowane przez nauczyciela. Ważne jest zatem, aby uwzględniały one indywidualne potrzeby rozwojowe i edukacyjne uczniów.

W trakcie zajęć z języka polskiego jako obcego może być stosowana m.in. metoda międzykulturowego portfolio. Polega ona na systematycznym dokumentowaniu przez uczniów rozwoju ich umiejętności językowych oraz doświadczeń międzykulturowych w formie prac, gromadzonych w specjalnie przygotowanej teczce lub segregatorze. Ważnym elementem tej metody jest monitorowanie i ewaluowanie ust. 11-14; Rozporządzenie Ministra Edukacji Narodowej z dnia 23 sierpnia 2017 r. w sprawie kształcenia osób niebędących obywatelami polskimi oraz osób będących obywatelami polskimi, które pobierały naukę $\mathrm{w}$ szkołach funkcjonujących $\mathrm{w}$ systemach oświaty innych państw (Dz.U. z 2017 r. poz. 1655), par. 16, ust. 1-9. 
własnych postępów w nauce języka oraz w zakresie rozwijania międzykulturowych kompetencji komunikacyjnych (Młynarczuk-Sokołowska, Szostak-Król 2016).

Niezwykle istotne jest także wspieranie uczniów w zakresie wyrównywania zaległości edukacyjnych, tak aby zapobiegać pogłębianiu się trudności, drugoroczności oraz ekskluzji edukacyjnej i społecznej. Nasze obserwacje wskazują, że wielu uczniów z doświadczeniem migracji nie byłoby $w$ stanie poradzić sobie $z$ realizacją podstawy programowej, gdyby nie uczestniczyło w spotkaniach wyrównawczych z wybranych przedmiotów. Prawodawstwo stwarza możliwość prowadzenia zajęć wyrównawczych ${ }^{6} \mathrm{z}$ różnych przedmiotów, w wymiarze jednej godziny tygodniowo. Organizuje je organ prowadzący szkołę w sytuacji, gdy nauczyciel prowadzący zajęcia edukacyjne z danego przedmiotu stwierdzi konieczność uzupełnienia różnic programowych przez ucznia z zagranicy.

Cudzoziemcy podejmujący naukę w szkole mają prawo do korzystania ze wsparcia osoby władającej językiem ich kraju pochodzenia, zatrudnionej w charakterze pomocy nauczyciela, nazywanej często asystentem międzykulturowym ${ }^{7}$. Placówka, w której znajdują się uczniowie z zagranicy, może wnioskować do organu prowadzącego o tego typu osobę. Obowiązki asystentów polegają na wielozakresowym wspieraniu zarówno uczniów (lingwistycznym, kulturowym, mediacyjnym itp.), jak i innych członków społeczności szkolnej oraz kadry pedagogicznej. Powinni oni przede wszystkim wspomagać dzieci językowo w początkowym okresie nauki w nowej szkole, brać udział w lekcjach (i np. wyjaśniać podopiecznym treści poleceń), towarzyszyć w odrabianiu prac domowych. Istotne jest również zapewnianie dzieciom poczucia bezpieczeństwa, ułatwienie im adaptacji w nowym środowisku szkolnym, m.in. przez przybliżanie nowego systemu pracy (w tym zasad i obowiązków) oraz motywowanie do partycypacji w życiu placówki. Częścią pracy asystenta jest także współpraca z rodzicami.

Ważnym czynnikiem inkluzji cudzoziemców jest ich znajomość języka ojczystego oraz rodzimej kultury i religii. Braki w tym zakresie mogą stanowić znaczną barierę $\mathrm{w}$ dostosowywaniu się do realiów nokształcenia osób niebędących obywatelami polskimi..., par. 18 ust. 1-3. 
wego kraju. Dlatego warto korzystać z możliwości organizowania cudzoziemcom nauki języka i kultury kraju pochodzenia ${ }^{8}$. Zajęcia w tym zakresie są najczęściej inicjowane przez organizacje pozarządowe w porozumieniu z dyrektorem szkoły i za zgodą organu prowadzącego placówkę.

Poza wskazanymi wcześniej formami wsparcia uczniowie cudzoziemscy mają także prawo do nauki religii ${ }^{\text {. }}$

\section{Zakończenie}

Jednym z priorytetów współczesnej edukacji jest rozwiązanie kwestii przygotowania uczniów z doświadczeniem migracji do pełnej partycypacji w życiu szkoły oraz całego społeczeństwa. Imigranci, uchodźcy oraz reemigranci, rozpoczynając naukę w polskich placówkach edukacyjnych, potrzebują niejednokrotnie wielopłaszczyznowego wsparcia, w związku z tym niezbędne jest systematyczne rozpoznawanie ich potrzeb. Bardzo ważnym czynnikiem efektywnej inkluzji i edukacji dzieci z doświadczeniem migracji jest odpowiednie przygotowanie kadry pedagogicznej. Oznacza to posiadanie przez nauczycieli kompetencji niezbędnych do pracy z tą grupą uczniów, znajomości prawnych możliwości ich wspierania (oddziały przygotowawcze, zajęcia z języka polskiego jako obcego, lekcje wyrównawcze itp.) oraz umiejętności działania z zespołem zróżnicowanym kulturowo. Nasze doświadczenia pokazują, że niezykle istotne są postawy otwarte, dostrzegające potencjał takich grup. Obecność dzieci z doświadczeniem migracji w przestrzeni edukacyjnej powinna być dla pedagogów, nauczycieli oraz ich szkolnych kolegów szansą, a nie obciążeniem. Umożliwia zaznajomienie się z innymi kulturami i językami, rozbudzenie ciekawości poznawczej, otwarcie się na bogactwo różnorodności i w tym kontekście rozwijanie własnej tożsamości. Stwarza także okazję do ciągłego kształcenia kompetencji międzykulturowych i uczenia się pokojowego koegzystowania w zróżnicowanym społeczeństwie. poz. 425); Rozporządzenie Ministra Edukacji Narodowej z dnia 14 kwietnia 1992 r. w sprawie warunków i sposobu organizowania nauki religii w publicznych przedszkolach i szkołach (Dz.U. z 1992 r. nr 36 poz. 155), par. 2 ust. 1-5. 